\title{
Causality Relationship of Zakat, Income Inequality, and Poverty: A Panel Co-Integration Approach
}

\author{
Submitted 06/07/20, $1^{\text {st }}$ revision $27 / 08 / 20$, $2^{\text {nd }}$ revision $29 / 09 / 20$, accepted $15 / 10 / 20$
}

\section{Abstract: \\ Suriani $^{1}$, Ridwan Nurdin ${ }^{2}$, Muhammad Haris Riyaldi ${ }^{3}$}

Purpose: This study aims to analyze the potential of Zakat in distribution income policy and the causality relationship of Zakat income inequality and poverty.

Design/Methodology/Approach: This study analyzes the causal relationship and the effect of Zakat, income inequality on poverty in 21 districts/cities of Aceh-Indonesia. To see the effect in the short and long term, time series analysis with Auto-Regressive Distributed Lag (ARDL) is used. The stages of the analysis test were carried out starting from the data stationarity test, optimal lag, cointegration test, and causality test.

Findings: The estimation results show that in the long run, Zakat has a negative effect on poverty and income inequality has a positive effect on poverty. However, in the short run, both Zakat and income inequality do not affect poverty. Supported by the results of the causality test which shows that there is a one-way causal relationship between Zakat and poverty and Zakat with income inequality. Likewise, income inequality has a one-way causal relationship to poverty.

Practical Implications: The findings of this research indicate that if the Zakat potential can be distributed optimally, then Zakat is the best policy solution to reduce poverty and income inequality.

Originality/Value: The difference in this research from previous studies is to review the potential for Zakat that has become a regional policy in Aceh and to test it against poverty alleviation using the income inequality variable as a control variable. The analysis is strengthened by analyzing the causal relationship between the three variables.

Keywords: Zakat, income inequality, poverty, cointegration.

JEL code: D63, E25, I32.

Paper type: Research Study.

Acknowledgments: Many thanks to Syiah Kuala University for facilitating and funding this research by the Institute for Research and Community Service (LPPM) Syiah Kuala University with Decree Number. 89 / UN11. 2.1 / PT.01.03 / PNBP / 2020.

${ }^{1}$ Corresponding author, Faculty of Economics and Business, Syiah Kuala University, Banda Aceh, Indonesia, e-mail: suriani@unsyiah.ac.id;

${ }^{2}$ Same as in 1,e-maiil: ridwanisa@unsyiah.ac.id;

${ }^{3}$ Same as in 1, e-mail: harisriyaldi@unsyiah.ac.id; 


\section{Introduction}

Development in every country has the same ultimate goal of achieving prosperity. The true nature of the development process carried out is continuous and sustainable or what is called Sustainable Development Goals or SDGs. The sustainable development goals have 17 goals by 169 measurable achievements that have been determined by the United Nations as a world development agenda for the benefit of humans and the planet that was published on 21 October 2015 (BPS, 2018). The sustainable development goal of this UN resolution is a continuation or replacement of the Millennium Development Goals (MDGs).

The first goal of sustainable development is the eradication of all forms of poverty. In this case, the Indonesian government has made efforts to reduce poverty levels in all regions with various poverty reduction programs. However, poverty still exists in Indonesia.

Figure 1. Poverty Level in Indonesia (2015-2019)

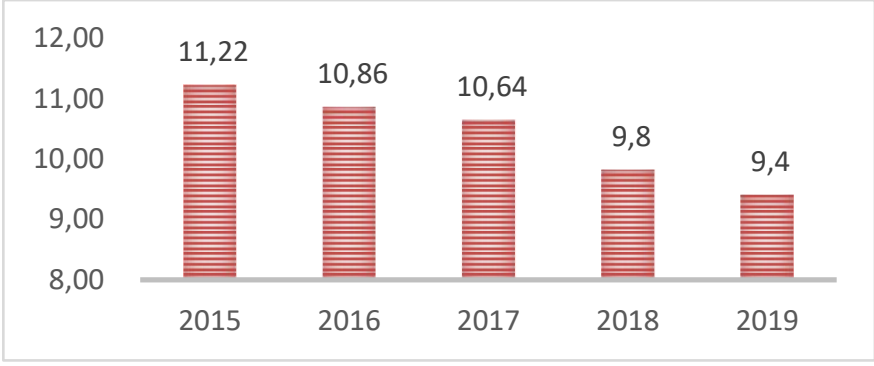

Source: Own study.

In Figure 1, it is shown that the poverty rate in Indonesia is decreasing every year. Shows the results of the national development process that has succeeded in improving the welfare of its population. The development process is not evenly distributed in Indonesia, or there are still disparities. Inequality in the development process can lead to regional income inequality, due to the unequal distribution of income. From the concept of Islamic economics, income distribution can be seen from the distribution of wealth of the rich to the poor through Zakat.

Zakat is an asset that must be issued by every Muslim or business entity to those entitled to receive it following the rules of Islamic law. Zakat has a dual function, namely as individual worship (Fardhiyyah) and Mu'amalah worship (economic and social). From the economic and social side, Zakat can pay attention to the benefit of the people. Indonesia is a country that has a majority Muslim population. Zakat has great potential to contribute to reducing poverty in Indonesia. BAZNAZ (National Zakat Agency) data shows that Indonesia's Zakat potential reaches IDR 286 trillion. The amount of Zakat collected in 2015 reaches IDR 3.6 trillion. An increase in the number of Zakat management organizations on their development is faster than other philanthropic institutions (Neraca, 2019). 
One of the Province in Indonesia that has a Muslim majority in Aceh Province. If it is related to the amount of Zakat available from Muslims, the poverty rate in Aceh should be lower than in other regions or comparable to the Province of Bali. Bali has a minority of Muslims or a majority of the population of non-Muslims (Hindu and Buddhist). Aceh's poverty is still above the national average poverty rate than Bali. Bali has a poverty rate that is low below the national level or at 3.79\%. Meanwhile, Indonesia's poverty rate is $9.41 \%$ of the total population (BPS, July 2019).

When viewed from the potential for Zakat in Aceh Province, Nazaruddin et al. (2014) state that the potential for Zakat in Aceh reaches 1.4 trillion / year. This great potential has been exploited by the people of Aceh or has not been realized in its implementation so that the welfare of the population can be achieved and reduce poverty levels. Zakat is related to the SDGs because it aims to alleviate poverty and is also supported by law. Number 232011 concerning Zakat management. The purpose of this law explains that the management of Zakat has the aim of increasing service efficiency in managing Zakat and increasing the benefits of Zakat to achieve the benefit of the people. Many previous studies that examined Zakat, namely Hassan and Noor (2015), examined whether capital assistance through the Zakat institution helps poor people.

The results of his research show that these institutions are very effective in distributing Zakat assistance to recipients. Also, an empirical study of Zakat has been conducted by Muhammad and Saad (2015) which confirms that moral attitudes and reasons significantly influence the intention to pay Zakat by entrepreneurs in Kano Nigeria. The results of some of these studies which show that Zakat has a positive impact on the environment are also strengthened by further research that explores the role of Zakat in sustainable development (Shaikh, 2019).

Previous research was mostly conducted on Zakat, Muzakki, and Mustahik institutions. Reduction of the poverty rate in Aceh Province. The poverty condition in the districts/cities of Aceh Province indicates that there is an inequality in income between these regions. Several previous studies have examined the relationship between income inequality and poverty (Borooah, Gustafsson, and Li, 2006), (Farzanegan and Habibpour, 2017) which concluded that if income inequality (Gini ratio decreases, the poverty rate also decreases).

The direction of the purpose of this study is to empirically analyze the relationship between the ability of Zakat and its effect on the first goal of sustainable development in Aceh Province as a research sample area. Several studies on Zakat and poverty have been widely carried out and some have used cointegration approaches such as research (Akram \& Afzal, 2014). The difference with this study, the control variable used here is the income inequality variable.

\section{Literature Review}


According to Islamic law, Zakat means an obligation for assets or an obligation for a certain number of assets for a certain group and for a certain time. Liability for a certain number of assets, means that Zakat is an obligation for assets that are binding and not proposed. This obligation is exposed to every Muslim (baligh or not, intelligent, or insane) when they have many assets that have met their nisab limit. This particular group is the mustakihin which is summarized in eight asnaf. The time to pay zkaat is when a year has passed (haul) for Zakat on gold, silver, trade, when harvesting for crops, when obtaining it for rikaz and when the month of Ramadan arrives before the 'Iid prayer for Zakat fitrah. The relationship between the meaning of Zakat according to language and terms is very close, namely that the assets that are spent on Zakat will be a blessing, grow, develop and become more holy and good (Hafidhuddin, 2002).

The function of Zakat in society is related to several things, namely (Fuadi, 2016); (a) Social responsibility (in terms of poverty alleviation, meeting minimum physical needs, providing employment opportunities and also social insurance); (b) The economy, namely by diverting stored and unproductive assets into circulation and productivity among the people, for example, the property of orphans and (c) the upholding of the soul of the people, namely through three principles: (1) perfecting the independence of each individual; (2) arousing a spirit of good deeds that are beneficial to the wider community, and (3) maintaining and maintaining faith.

In general, the slices between SDGs and Zakat meet in an objective to reduce poverty, including hunger that occurs in this world and its various derivatives. Several opinions and views have emerged trying to link the SDGs points one by one with the interpretation of Zakat work, especially from the point of view of beneficiaries and Zakat allocation. For example, there is an opinion that says that the contribution of Zakat to SDGs currently focuses on 5 goals, namely:

Goal 1: Eliminating poverty,

Goal 2: Ending hunger,

Goal 3: Good health and well-being,

Goal 4: Quality Education, and

Goal 5: Water clean and sanitary.

There is also an opinion that states that each SDG's goal is points that are entirely under Zakat, or to be more precise, can be supported by Zakat work (Baznas, 2017).

Zakat as one of the pillars of Islam has an important role in the real world. Zakat is a certain right in the wealth of rich people that must be given to Asnaf. Asnaf who are entitled to receive Zakat are indigent, poor, amil, converts (new siblings), servants, people in debt, fii sabilillah and ibn sabil. The discussion regarding the utilization of Zakat always has a connection with the concept that discusses the background and purpose of distributing Zakat to improve the standard of life of the recipients of Zakat. As explained in Sahata (2005), Tarimin (2005) and Basyariah (2011) which states that 
Zakat is a fund that is collected and managed properly so that it will be able to raise the level of economic life for the needy and poor.

The important thing is that Zakat does not eliminate the circulation of wealth and it does not balance the distribution of wealth among human activities. One of the human economic activities is production. In this case, Alim (2015) explains that the Zakat regulation provides the opportunity to use Zakat for productive purposes. The Zakat instrument will encourage consumption and investment and reduce the hoarding of assets (Priyono, 2017).

In the context of solving poverty, Islam teaches that every individual Muslim is obliged to work and try to find sustenance. By working, a person can provide for himself and his family without needing help from others. Besides, Islam also places a big responsibility which is a pillar of religion on Muslims who can help weak people by paying Zakat. Beik (2010) analyzes in detail the function of Zakat in reducing poverty and increasing people's income, when Hartoyo and Sari (2010), Anriani (2010) and Tsani (2010) have discussed the implications of using Zakat in reducing the level of poverty in Indonesia.

Qardhawi emphasized that the group most entitled to receive Zakat is the poor. The achievement of the goal of using Zakat in overcoming the problem of poverty is carried out utilizing distributing Zakat according to the circumstances of the Zakat recipients. Ahmed (2004) describes two categories of the needy and the poor who are given Zakat in the form of productive and consumptive Zakat.

\section{Methodology}

This study analyzes the relationship between the primacy of Zakat and its effect on sustainable development in Aceh Province ( 21 districts/cities) by using indicators that are used as a measure in this study, namely by considering the poverty variable. The annual data period used is 2010 to 2019. For the quantitative research methodology approach, modeling with panel analysis is used, namely the OLS (Ordinary Least Square) analysis method with multiple linear regression equations (multiple linear regression). Panel analysis is to combine time series and cross-section data. To see the effect in the short and long term, time series analysis with Auto-Regressive Distributed Lag (ARDL) is used. This model was introduced by Pesaran et al. (2001). The purpose of using ARDL panel data regression is to obtain the results of the estimation of each characteristic variable separately, assuming there is a cointegrated lag in each variable.

The ARDL panel data regression equation is transformed directly into the model for this research variable into: 


$$
\begin{aligned}
& \Delta \operatorname{Pov}_{j, t}=\alpha_{0 \mathrm{i}}+\sum_{i=1}^{n} a_{1 i} \Delta \operatorname{Pov}_{i, t-1}+\sum_{i=1}^{n} a_{2 i} \Delta Z_{i, t-1}+ \\
& \sum_{i=1}^{n} a_{3 i} \Delta G R_{i, t-1}+\beta_{11} \operatorname{Pov}_{j, t-1}+\beta_{21} Z_{j, t-1}+\beta_{31} G R_{j, t-1}+\varepsilon_{j, t}
\end{aligned}
$$

Information for Equation 1 where Pov is poverty, $Z$ is Zakat, and GR is income inequality from 21 districts/cities, $a_{1}$ to $a_{3}$ are short-term coefficients, $\beta_{1}$ to $\beta_{1}$ are longrun coefficients, $\mathrm{t}$ is the period/years $2008-2019, j$ is $21 \mathrm{districts/cities,} i$ is the lag sequence and $\varepsilon$ is the error term.

\subsection{Stationarity Test}

The important thing to do before analyzing time series data is the stationarity test of the data. The goal in stationary testing is to prove that the regression result data does not contain a unit root or the data is stationary and pay attention to the absence of spurious regression on the relationship between the dependent variable and the independent variable (Novalina and Rusiadi, 2018). It is said to be stationary in data with constant assumptions on the mean and variance. When performing the stationarity test, the analytical tool used was the unit root test, introduced by David Dickey and Wayne Fuller so that it is known as the Dickey-Fuller (DF) unit root test.

Time series data usually have problems with non-stationary data which will result in the R2 value is large and the t-test value is significant but has no value or is commonly called false regression or dubious regression (spurious regression). Then it is necessary to test the data or make the data stationary, for that the method used is the common unit root consisting of the Levin, Lin, and Chu (LLC) and Breitung's test statistics, as well as the individual unit root consisting of the Im, Pesaran, and Shin (IPS) tests. , ADF - Augmented Dickey-Fuller, and PP-Philip Peron Fisher (Soebagiyo, 2007). The stationarity test equation can be written as follows:

$$
Y_{t}=\rho Y_{t-1}+u_{t} \rightarrow \Delta Y_{t}=(\rho-1) Y_{t-1}+u_{t}=\delta Y_{t-1}+u_{t}
$$

In the hypothesis, if you accept $\mathrm{H} 0$, this means that $\rho=1$ so that the data is said to contain unit root or data is not stationary, on the contrary, if you reject $\mathrm{H} 0$, this means that $\rho<1$ so that the data is said to have no unit root or the data is stationary. When the stationarity test has been carried out and states that the panel data contains stationary or does not have a unit root, the next estimate can be made.

\subsection{Cointegration Test}

The ARDL Panel model is accepted if the model has a cointegration lag, assuming the coefficient value has a negative slope and a significant level $<0.05$ or 5 percent. The cointegration test must be performed on data estimation because it avoids the fake regression phenomenon. The cointegration test used is shown in the following equation (Pesaran and Shin, 1995; Perasan et al., 2001). 


$$
\begin{aligned}
Y_{t}= & a_{0}+a_{1} t+\sum_{i=1}^{p} a_{2} Y_{t-i}+\sum_{i=0}^{q} a_{3} Y_{1 t-i}+\sum_{i=0}^{r} a_{4} Y_{2 t-i}+ \\
& \sum_{i=0}^{s} a_{5} Y_{3 t-i}+e_{t}
\end{aligned}
$$

Where the hypothesis in the cointegration test is: If there is no long-term relationship: $\mathrm{H} 0=\alpha 1=\alpha 2=\alpha \mathrm{n}=1$ and if there is a long-term relationship; $\mathrm{H} 1 \neq \alpha 1 \neq \alpha 2 \neq \alpha \mathrm{n} \neq 1$

In this study, the ARDL panel data cointegration test was carried out by (1) the Kao Test (Kao Residual Cointegration Test). Kao in Baltagi (2005) to test cointegration in panel data, using a residual approach from the DF and ADF tests by adopting the Eagle-Granger procedure. Kao developed the DF and ADF statistical tests, the data is said to be co-integrated if the probability value in the Kao test is smaller than $\alpha=0.05$ or 5 percent and if the coefficient statistical value is negative. (2). Pedroni Test (Pedroni Residual Cointegration Test). Pedroni provides a Philip-Perron test to make data cointegrated using the panel data autoregressive coefficient estimator. The data is said to be co-integrated if the probability value is smaller than $\alpha=0.05$ or 5 percent and if the coefficient statistical value is negative.

From the two tests discussed, the Kao test and the Pedroni test both use residuals in testing panel data cointegration. Furthermore, knowing cointegrated or non-cointegrated data is by comparing the t-statistic value or the probability value. When the $t$ statistic value of the Kao or Pedroni test is greater than the t-critical value, the data is considered to have no cointegration or no long-term relationship, then it can accept H0. Conversely, if the t-statistic value in the Kao or Pedroni test is smaller than the tcritical value, then the data is considered cointegrated or there is a long-term relationship rejecting $\mathrm{H} 0$. In this paper, the cointegration test presented is Pedroni by comparing the regression results between within-dimension and between-dimension in the selection of regression models without trend and with the trend.

\section{Results and Discussion}

The test on the unit root panel found that there were differences in the stationarity of the data at the level and the first difference level. This can be seen using the LLC, IPS, ADF-Fisher, and PP-Fisher test approach with individual intercept.

The results of the stationary test show that each stationary variable is different at the level or (0) and the first difference or I (1). For the PPOV variable, the level for without trend and trend is stationary in LLC, but not stationary in ADF-Fisher and PPFisher. However, at the first difference level, both without trend and with a stationary trend in PP-Fisher at $1 \%$.

For the LZakat variable in the test without trend, the level is stationary in PP-Fisher, but in LLC and ADF-Fisher, it is not stationary (significance at $\alpha=1$ to 5 percent). Meanwhile, in the trend test, the LJPM variable was not stationary only in the ADF- 
Fisher test, while in the LLC and PP-Fisher it was stationary. Then the test results for the physical difference level in conditions without a trend and trend show that the LZakat variable has been standardized in all tests. From the test results, it can be concluded that each variable has a different integration, so it is necessary to do a cointegration test.

\subsection{Stationarity Data}

The unit test results, and the optimal lag test are needed to determine the optimal lag for regression. The optimal lag is shown to be at optimal lag 1 (SC and HQ) and lag 4 (LR, FPE, and AIC) (Table 1 and Table 2).

Table 1. Unit Roots Test Results

\begin{tabular}{|c|c|c|c|}
\hline \multicolumn{4}{|c|}{ Without Trend } \\
\hline Variables & LLC & ADF-Fisher & PP-Fisher \\
\hline Ppov & $\begin{array}{l}-6.2202 \\
(0.0000)\end{array}$ & $\begin{array}{l}38.8132 \\
(0.6117)\end{array}$ & $\begin{array}{l}44.0890 \\
(0.3833) \\
\end{array}$ \\
\hline $\begin{array}{l}\text { LZa- } \\
\text { kat }\end{array}$ & $\begin{array}{l}-2.8275 \\
(0.0023)\end{array}$ & $\begin{array}{l}33.8114 \\
(0.8119)\end{array}$ & $\begin{array}{l}52.7279 \\
(0.1241)\end{array}$ \\
\hline GR & $\begin{array}{l}-3.9939 \\
(0.0000)\end{array}$ & $\begin{array}{l}51.6090 \\
(0.1470)\end{array}$ & $\begin{array}{l}82.8718 \\
(0.0002)\end{array}$ \\
\hline$\Delta$ Ppov & $\begin{array}{l}-1.4799 \\
(0.0694)\end{array}$ & $\begin{array}{l}35.0223 \\
(0.7686)\end{array}$ & $\begin{array}{l}89.1071 \\
(0.0002)\end{array}$ \\
\hline$\Delta$ LZakat & $\begin{array}{l}-5.5435 \\
(0.0000)\end{array}$ & $\begin{array}{l}69.4655 \\
(0.0049)\end{array}$ & $\begin{array}{l}165.102 \\
(0.0000)\end{array}$ \\
\hline$\Delta \mathrm{GR}$ & $\begin{array}{l}-15.988 \\
(0.0000)\end{array}$ & $\begin{array}{l}95.7566 \\
(0.0000)\end{array}$ & $\begin{array}{l}193.974 \\
(0.0000)\end{array}$ \\
\hline \multicolumn{4}{|c|}{ With Trend } \\
\hline Ppov & $\begin{array}{l}-5.5020 \\
(0,0000) \\
\end{array}$ & $\begin{array}{c}33.2051 \\
(0.8320) \\
\end{array}$ & $\begin{array}{l}16.8854 \\
(0.9998) \\
\end{array}$ \\
\hline $\begin{array}{l}\text { LZa- } \\
\text { kat }\end{array}$ & $\begin{array}{c}-5.0390 \\
(0.0000)\end{array}$ & $\begin{array}{l}42.7018 \\
(0.4408)\end{array}$ & $\begin{array}{l}84.5201 \\
(0.0001)\end{array}$ \\
\hline GR & $\begin{array}{l}-15.988 \\
(0.0000)\end{array}$ & $\begin{array}{l}95.7566 \\
(0.0000)\end{array}$ & $\begin{array}{l}193.974 \\
(0.0000)\end{array}$ \\
\hline$\Delta$ Ppov & $\begin{array}{l}-1.4799 \\
(0.0694)\end{array}$ & $\begin{array}{l}35.0223 \\
(0.7686)\end{array}$ & $\begin{array}{l}89.1071 \\
(0.0000)\end{array}$ \\
\hline$\Delta$ LZakat & $\begin{array}{l}-4.9810 \\
(0.0000)\end{array}$ & $\begin{array}{l}39.8960 \\
(0.5637)\end{array}$ & $\begin{array}{l}152.431 \\
(0.0000)\end{array}$ \\
\hline$\Delta \mathrm{GR}$ & $\begin{array}{l}176.964 \\
(0.0000)\end{array}$ & $\begin{array}{l}85.3938 \\
(0.0001)\end{array}$ & \\
\hline
\end{tabular}

Note: (.) Is a t-statistic. Significance Level *** (1\%), **(5\%) and * (10\%)

Source: Own study.

The Optimal-Lag Test is presented in Table 2. 
Table 2. Optimal Lag results

\begin{tabular}{|c|c|c|c|c|c|c|}
\hline Lag & LogL & LR & FPE & AIC & SC & HQ \\
\hline 0 & -246.6186 & NA & 0.0105 & 3.9622 & 4.0297 & 3.9896 \\
\hline 1 & 115.5583 & 701.3585 & $3.88 \mathrm{e}-05$ & -1.6438 & $-1.3737 *$ & $-1.5340^{*}$ \\
\hline 2 & 124.9342 & 17.7100 & $3.86 \mathrm{e}-05$ & -1.6497 & -1.1770 & -1.4577 \\
\hline 3 & 143.7179 & 34.5860 & $3.30 \mathrm{e}-05$ & -1.8050 & -1.1297 & -1.5307 \\
\hline 4 & 154.6429 & $19.5955^{*}$ & $3.21 \mathrm{e}-05^{*}$ & $-1.8356^{*}$ & -0.9577 & -1.4789 \\
\hline
\end{tabular}

Source: Own study.

\subsection{Cointegration Test Results}

The results of the cointegration test are shown in Table 3, namely using a panel cointegration approach with Pedroni at $1-5 \%$ and reinforced by Kao at a significance level of $5 \%$, it can be said that there is cointegration between Zakat, income inequality, and poverty alleviation. This also means that the realization of Zakat and income inequality of the population in 21 districts/cities in Aceh Province has a short-term to longterm equilibrium relationship (cointegration).

Table 3. Panel Cointegration

\begin{tabular}{|l|l|l|}
\hline Cointegration Test & Within-Dimension \\
\hline Pedroni Cointegration Test & Without Trend & With Tren \\
\hline Panel v-Statistik & $0.3392(0.3672)$ & $3.5279(0.0002)$ \\
\hline Panel rho-Statistik & $1.9029(0.9715)$ & $3.9793(1.0000)$ \\
\hline Panel PP-Statistik & $-1.4174(0.0782)$ & $-0.3221(0.3737)$ \\
\hline Panel ADF-Statistik & $-1.9980(0.0229)$ & $0.2860(0.6126)$ \\
\hline \multicolumn{3}{|l|}{} \\
\hline Group rho-Statistic & Between-Dimension \\
\hline Group PP-Statistic & $3.9349(1.0000)$ & $5.7664(1.0000)$ \\
\hline Group ADF-Statistic & $-1.6099(0.0537)$ & $0.6415(0.7394)$ \\
\hline Kao Cointegration Test & $-2.9051(0.0018)$ & $0.4483(0.6730)$ \\
\hline ADF & $-1.6552(0.0489)$ \\
\hline
\end{tabular}

Source: Own study.

\subsection{Regression Test Results}

To analyze the effect of Zakat on poverty in Aceh Province, it can be explained from the regression results in Table 4. It shows that there is an effect of Zakat and income inequality in the long run, even though it does not affect in the short term. Zakat has a negative effect on poverty. It means that Zakat as Islamic economic philanthropy has the potential to support government programs in poverty alleviation. The effect shown in the results of this regression is -2.359694 . If there is an increase of one percent of Zakat realization, then poverty is predicted to decrease by $2.36 \%$. The results of this study are supported by research by Akram and Afzal (2014) which states 
that their regression with ARDL modeling shows that there is an inverse relationship between poverty and Zakat disbursement both in the short and long term.

Table 4. Estimation Results

\begin{tabular}{|c|c|c|c|c|}
\hline Variables & Coefficients & Se & t-Statistic & Prob \\
\hline \multicolumn{5}{|l|}{ Long run } \\
\hline LZakat & -2.3597 & 0.3883 & -6.0775 & $0.0000 * * *$ \\
\hline GR & 95.2452 & 20.4429 & 4.6591 & $0.0000 * * *$ \\
\hline \multicolumn{5}{|l|}{ Short run } \\
\hline Cointeg01 & -0.0629 & 0.0283 & -2.2261 & $0.0278 * * *$ \\
\hline DLZakat & 0.1314 & 0.1953 & 0.6729 & 0.5023 \\
\hline DGR & -2.6931 & 2.0154 & -1.3362 & 0.1839 \\
\hline $\mathrm{C}$ & 2.0289 & 1.1828 & 1.7153 & $0.0888 *$ \\
\hline
\end{tabular}

Note: (.) Is a t-statistic. Significance Level *** (1\%), **(5\%) and * (10\%)

Source: Own study.

Income inequality has a positive effect in the long run. This indicates that if there is an increase in one unit of income inequality, it will increase poverty in districts/cities, which is predicted to be 95.24. Luo, Li, and Sicular (2020) who examined the evolution of national income inequality influence reducing poverty with the existence of income redistributive policies. This means that if income inequality decreases the impact of income redistributive indicates that there has been faster income growth so that poverty can be reduced.

The regression results show that there is an effect of a short-term to long-term equilibrium relationship from the Cointeg01 value which is negative and significant at 5 $\%$. It is known that Zakat is issued by the mustahik when the nisab of assets has reached the haul, which is for 1 year. However, it is possible, if the potential for Zakat can be realized optimally at any time, then it could be that Zakat can affect poverty reduction in the short term. The results of this study also imply that if the Zakat potential in Aceh Province can be optimally realized, then poverty can be reduced even further.

\subsection{Causality Test Results}

The findings of the causality test in Table 5 show that there is a one-way causal relationship between Zakat and poverty and Zakat with income inequality. Likewise, income inequality has a one-way causal relationship to poverty. The model of causality in this study can be described in a diagrammatic manner as follows in Figure 1.

This shows that if the potential for Zakat can be distributed and realized optimally, then Zakat can also affect poverty reduction and income inequality. It has meant that Zakat is one of the right income distribution systems to reduce income inequality. This is following the objectives of the Aceh government policy as stipulated in the Qanun 
Zakat, which is to improve the benefit of the people in Aceh Province-Indonesia. Almost the same as the research of Luo et al., (2020) the income redistributive policy system that has been implemented in China but not Zakat.

Table 5. Causality Test

\begin{tabular}{|l|l|l|l|}
\hline Null Hypothesis: & Obs & F-Statistic & Prob \\
\hline LZakat does not Granger Cause Pov & 126 & 7.6814 & 2. E-05 \\
\hline Pov does not Granger Cause LZakat & & 0.8253 & 0.5116 \\
\hline GR does not Granger Cause Pov & 126 & 2.1839 & 0.0750 \\
\hline Pov does not Granger Cause GR & & 0.3563 & 0.8392 \\
\hline GR does not Granger Cause LZakat & 126 & 1.8510 & 0.1237 \\
\hline LZakat does not Granger Cause GR & & 2.8849 & 0.0255 \\
\hline
\end{tabular}

Source: Own study.

Figure 2. Causality Relationship Model

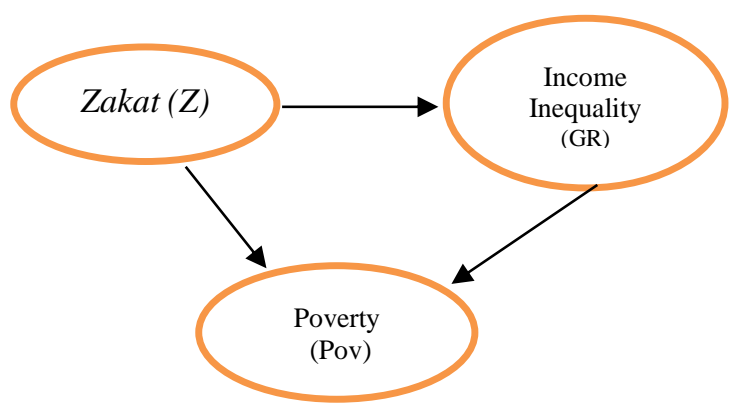

Source: Own study.

\section{Conclusion}

The potential for Zakat is very large in Aceh Province because the population is majority Muslim. The results of this study explain that zakat has a negative effect on poverty and income inequality has a positive impact on poverty. The results of the causality relationship test strengthen the influence of Zakat and income inequality on poverty.

The results show that Zakat has a one-way causality relationship to poverty and income inequality. It means that if the distribution of Zakat has done optimally, it can reduce poverty and income inequality. Then inequality also has a one-way causality relationship to poverty. It implies that there is a close relationship between income inequality and poverty. If income inequality increases, then poverty will also increase. Therefore. it is hoped that income inequality in 21 districts/cities in Aceh Province can be reduced and the distribution of Zakat can be optimized. 


\section{References:}

Ahmed, H. 2004. Role of Zakah and Awqaf in Poverty Alleviation, Occasional Paper No.8, Jeddah, Islamic Research and Training Institute (IRTI) Islamic Development Bank.

Akram, M.M., Afzal, M. 2014. Dynamic Role of Zakat in Alleviating Poverty: A Case Study of Pakistan. Munich Personal RePEc Archive, 56013.

Alim, M.N. 2015. Utilization and Accounting of Zakat for Productive Purposes in Indonesia: A Review, 211, 232-236. https://doi.org/10.1016/j.sbspro.2015.11.028

Anriani. 2010. Analisis Dampak Zakat Terhadap Tingkat Kemiskinan Mustahik (Studi Kasus: Pendayagunaan Zakat oleh BAZ Kota Bogor di Tiga Kecamatan Kota Bogor) [Analysis of the Impact of Zakat on Mustahik Poverty Level (Case Study: Zakat Utilization by BAZ Bogor City in Three Districts of Bogor City)]. Masteral Thesis. Bogor (ID): Bogor Agricultural University.

Basyariah, S. 2010. Pemberdayaan Zakat Produktif [Productive Zakat Empowerment]. Jurnal A-Tasyri, Vol. II, No.1, Melaboh, Sekolah Tinggi Agama Islam (STAI) Teungku Dirundeng.

BAZNAS. 2017. Sebuah Kajian Zakat on SDG's [A study of Zakat on SDGs]. Jakarta: Puskas BAZNAS.

Beik, I.S. 2010. Peran Zakat Mengentaskan Kemiskinan dan Kesenjangan [The Role of Zakat Alleviates Poverty and Inequality]. Iqtishodia-Jurnal Ekonomi Islam Republika, July 29, 2010.

Borooah, V.K., Gustafsson, B., Li, S. 2006. China and India: Income inequality and poverty north and south of the Himalayas. Journal of Asian Economics, 17(5), 797-817. https://doi.org/10.1016/j.asieco.2006.08.001

Central Bureau of Statistics. 2018. Indikator Sdgs Provinsi Aceh 2018 [SDGs Indicators for Aceh Province 2018]. https://aceh.bps.go.id/publication.

Farzanegan, M.R., Habibpour, M.M. 2017. Resource rents distribution, income inequality and poverty in Iran. Energy Economics, 66, 35-42. https://doi.org/10.1016/j.eneco.2017.05.02

Fuadi. 2016. Zakat Dalam Sistem Hukum Pemerintahan Aceh (Zakat in the Aceh Government Legal System). Yogyakarta, Deepublish.

Hafidhuddin, D. 2007. Zakat Dalam Perekonomian Modern (Zakat in the Modern Economy). Jakarta: Gema Insane Pers.

Hartoyo, S., Sari, N.P. 2010. Pengentasan Kemiskinan Berbasis Zakat: Studi Kasus di Garut. Iqtishodia-Jurnal Ekonomi Islam Republika.

Kao, C. 1999. Spurious regression and residual-based tests for cointegration in panel data. Journal of Econometrics, 90(1), 1-44. https://doi.org/10.1016/S03044076(98)00023-2

Luo, C., Li, S., Sicular, T. 2020. The long-term evolution of national income inequality and rural poverty in China. China Economic Review, 62, 101465. https://doi.org/10.1016/j.chieco.2020.101465.

Muhammad, S.A., Saad, R.Al.J. 2015. Moderating effect of attitude toward Zakat payment on the relationship between moral reasoning and intention to pay Zakat. Procedia Social and Behavioral Sciences, 219, 520-527.

Noor, Z. 2017. Peran Zakat dalam Mendukung Tujuan Pembangunan Berkelanjutan (The Role of Zakat in Supporting the Sustainable Development Goals). Jakarta, UNDP \& BAZNAS.

Novalina, A., Rusiadi. 2018. Leading Indikator Stabilitas Ekonomi Di Negara Civi (China, 
India, Vietnam dan Indonesia) Pendekatan Panel Ardl [Leading Indicators of Economic Stability in Civi Countries (China, India, Vietnam and Indonesia) Ardl Panel Approach. 4(1), 1-12.

Pesaran, M.H., Sin, Y., Smith, R.J. 2001. Bounds testing approaches to the analysis of level relationships. Journal of Applied Econometrics, 16(3), 289-326. https://doi.org/10.1002/jae.616.

Priyono, S. 2017. Zakat sebagai instrumen dalam kebijakan fiskal (Zakat as an instrument in fiscal policy). Al-Maslahah: Jurnal Hukum dan Pranata Soial Islam.

Sahata, H. 2005. Muhasabah az-Zakah. Cairo, Dar el-Syuruq.

Shaikh, S.A., Ismail, A.G. 2017. Role of Zakat in Sustainable Development Goals. International Journal of Zakat, 2, 1-9.

Sudira, P. 2009. Studi Mandiri (Grounded Theory Independent Study). Yogyakarta, UNY.

Tarimin, M. 2011. Memperkasa Ijtihad Hukum Agihan Dana Zakat: Satu Saranan Penjanaan Semula Fiqh Al-Masarif Al-Zakat. Transformasi Zakat: Daripada Saradiri Kepada Zakat Produktif. Pusat Urus Zakat, MAINPP \& Pusat Kajian Pengurusan Pemabangunan (ISDEV).

Qardhawi, Y. 2009. Kemiskinan dan Cara Islam Mengatasinya (Poverty and the Islamic Way to Overcome It). Terjemahan Arsil Ibrahim, Kuala Lumpur, YaPEIM 